\title{
A Systematic Review for Vaccine-Preventable Diseases on Ships: Evidence for Cross-Border Transmission and for Pre-Employment Immunization Need
}

\author{
Varvara A. Mouchtouri ${ }^{1, \dagger}{ }^{\dagger}$, Hannah C. Lewis ${ }^{2, \dagger}$, Christos Hadjichristodoulou ${ }^{1, *}$ and \\ the EU SHIPSAN ACT Joint Action Partnership \\ 1 Department of Hygiene and Epidemiology, Faculty of Medicine, University of Thessaly, 41222 Larissa, Greece \\ 2 Department of Infectious Disease Epidemiology, Robert Koch Institute, 13353 Berlin, Germany \\ * Correspondence: xhatzi@med.uth.gr; Tel.: +0030-2410-565050 \\ + These authors contributed equally to this research. \\ $\ddagger$ Author group: the EU SHIPSAN ACT joint action partnership: Despena Andrioti, Anastasia Barbouni, \\ Miguel Dávila-Cornejo, Martin Dirksen-Fischer, Mauro Dionisio, Rita Ferrelli, Brigita Kairienè, Galina \\ Kokosharova, Angel Kunchev, Peter Otorepec, Robertas Petraitis, Rimantas Pilipavicius, Carman Varela \\ Martinez, Natalja Vozelevskaja, Dominique Wagner.
}

Received: 20 June 2019; Accepted: 25 July 2019; Published: 30 July 2019

\begin{abstract}
A literature review was conducted to identify evidence of cases and outbreaks of vaccine-preventable diseases (VPDs) that have been reported from on board ships and the methods applied on board for prevention and control, worldwide, in 1990 to April 2019. Moreover, evidence from seroprevalence studies for the same diseases were also included. The literature review was conducted according to Preferred Reporting Items for Systematic reviews (PRISMA) guidelines. A total of 1795 cases (115 outbreaks, 7 case reports) were identified, the majority were among crew $(1466 / 1795,81.7 \%)$ and were varicella cases $(1497,83.4 \%)$. The origin of crew cases was from sub-tropical countries in many reports. Measles (40 cases, $69 \%$ among crew), rubella $(47,88.7 \%)$, herpes zoster $(9,69.2 \%)$ and varicella cases $(1316,87.9 \%)$ were more frequent among crew. Mumps cases were equal among passengers and crew (22/22). Hepatitis A (73/92, 70.3\%), meningococcal meningitis $(16 / 29,44.8 \%)$, and pertussis (9/9) were more frequent among passengers. Two outbreaks resulted in 262 secondary measles cases on land. Review results were used to draft a new chapter for prevention and control of VPDs in the European Manual for Hygiene Standards and Communicable Disease Surveillance on Passenger Ships. Despite past and current evidence for cross-border VPD transmission and maritime occupational risks, documented pre-employment examination of immune status, vaccination of seafarers, and travel advice to passengers are not yet regulated.
\end{abstract}

Keywords: vaccine; cruise; ship; travel; maritime health; varicella; chickenpox; mumps; rubella; measles; pertussis; diphtheria; meningococcal disease; hepatitis A; vaccination; occupational health; seafarers; sailors

\section{Introduction}

Ships are long acknowledged as semi-closed and densely populated environments with close living and sleeping quarters, and shared water, ventilation and sewage systems [1-3]. Such environments are accountable to a constant flux of people from over the world and conducive for the spread of communicable diseases.

Approximately 397 million passengers embarked and disembarked in European Union (EU) ports in 2016 [4]. It was estimated that 26.6 million tourists spent holidays on cruise ships worldwide in 
2017 [5], while a total of 1,647,500 seafarers work on merchant ships operating internationally over the world [6]. The risk of cases and outbreaks of disease among the population on board ships is ever present.

Outbreaks of norovirus and influenza, as well as food and waterborne disease, are well documented [7-10]. In recent years, outbreaks of diseases, which could be prevented by routine vaccines (e.g., measles, rubella, and varicella) have also been reported on ships [11,12]. This is not surprising as both crew and passengers originate from diverse countries with variable vaccine schedules and coverage. However, even in countries where measles was declared eliminated, land-based community outbreaks are currently ongoing [13]. In response to these events, governments and international agencies have developed national [14] and international guidelines $[15,16]$ to provide advice for timely prevention and control.

In light of events constituting cross-border health threats under the legal framework of the International Health Regulations (2005) and the Decision no 1082/2013/EU on serious cross-border threats to health, updated European guidance was also requested by EU Member States [17,18]. As such, the EU SHIPSAN ACT joint action [19] chose to update the "European Manual for Hygiene Standards and Communicable Disease Surveillance on Passenger Ships" to include a chapter on vaccine-preventable diseases (VPDs) [16]. In writing up-to-date guidelines on VPDs, the evidence-base for the occurrence of disease and characteristics of outbreaks or other events that could be prevented by routine vaccination, on ships, and the methods applied for their prevention and control, was reviewed. To our knowledge there has been no other review published with this objective.

\section{Materials and Methods}

\subsection{Research Question and Objectives}

The bibliographic review was conducted in order to answer the following research questions:

1. What is the published evidence of cases and outbreaks of measles, mumps, rubella, varicella, diphtheria, tetanus, pertussis, meningococcal disease, hepatitis $\mathrm{A}$, and hepatitis $\mathrm{B}$ that have been reported from on board ships and the methods applied on board for the prevention and control, worldwide, since 1990?

2. What is the published evidence of exposure of travelers to measles, mumps, rubella, varicella, diphtheria, tetanus, pertussis, meningococcal disease, hepatitis A, and hepatitis B, based on serological examinations, worldwide, since 1990?

This review aims at giving an insight on VPDs on board ships that have occurred worldwide, by analyzing evidence published since 1990. Results of this review were used in the revision of the "European Manual for Hygiene Standards and Communicable Disease Surveillance on Passenger Ships" [16].

The specific objectives of the review were the following:

- To undertake descriptive epidemiology (person, place and time characteristics) of cases and outbreaks of VPDs (measles, mumps, rubella, varicella, diphtheria, tetanus, pertussis, meningococcal disease, hepatitis $\mathrm{A}$, and hepatitis $\mathrm{B}$ ) that have been reported from on board ships since 1990.

- To describe the cause/risk factors identified for introduction and transmission of these VPDs onto ships.

- $\quad$ To describe key methods applied for the prevention and control of these VPDs on ships.

\subsection{Search Strategy}

The search concepts used for the above-mentioned topic are: (a) Public health event: Cases or outbreaks, or evidence for exposure based on serological examinations to VPDs including measles, mumps, rubella, varicella, herpes zoster, diphtheria, tetanus, pertussis, meningococcal disease, hepatitis 
A, and hepatitis B; (b) type of intervention: Prevention and control measures of those VPD; (c) population of interest: Humans travelling with ships; (d) setting: Ships; (e) outcome: Effectiveness of measures applied, cost, public health impact.

The systematic review was performed according to the procedures and checklist outlined by the Preferred Reporting Items for Systematic reviews (PRISMA) [20]. To retrieve information, Pubmed was searched for relevant articles published between 1 January 1990 and 30 April 2019 in English, German or Greek. Moreover, the German Institute of Medical Documentation and Information (DIMDI) databases (includes Medline, Embase, Embase Alert, Biosis Previews, SciSearch) were searched for relevant articles published between 1 January 1990 and 15 July 2015 in any of the official EU languages. All text fields were searched using the following search terms:

(ship OR ferry* OR boat* OR yacht* OR cruise* OR barge* OR "fishing vessel" OR tanker* OR "on board" OR aboard OR "maritime transport") AND (chickenpox OR diphtheria OR "German measles" OR hepatitis A OR hepatitis B OR measles OR "meningococcal disease" OR meningitis OR mumps OR pertussis OR rubella OR tetanus OR varicella). An asterix was used for abridged terms. Within articles selected for full-text analysis, the reference lists were checked for completeness.

The SHIPSAN TRAINET communication platform was searched for relevant vaccine-preventable disease cases or outbreaks between 29 March of 2011 (establishment of platform) and 30 April 2019 [21]. Furthermore, the World Health Organization, the European Centre for Disease Prevention and Control (ECDC) and the United States Centers for Disease Control and Prevention (US-CDC) Division of Global Migration and Quarantine (DGMQ) were contacted separately for surveillance or outbreak reports relating to VPDs outbreaks on ships.

\subsection{Inclusion and Exclusion Criteria}

Inclusion criteria were: Articles or reports or record reviews or other documents published in peer-reviewed journals or national and international organizations' publications or information through personal communications, from January 1990 until April 2019, that reported any seroprevalence evidence or clinically and/or laboratory confirmed case or outbreak of measles, mumps, rubella, varicella, diphtheria, tetanus, pertussis, meningococcal disease, hepatitis $\mathrm{A}$, and hepatitis $\mathrm{B}$, on board ships sailing worldwide.

Exclusion criteria were: Publications reporting influenza were excluded from the review since there was existing recommended policy in the "European Manual for Hygiene Standards and Communicable Disease Surveillance on Passenger Ships" [16]. Moreover, those VPDs where there was not considered a risk specifically related to ships (e.g., Japanese encephalitis, rabies) and for risk groups based on age, occupation, underlying health condition, etc. (e.g., pneumococcal disease, rotavirus) were also excluded. Articles for which the full text was not available in English or German or Greek were also excluded. Moreover, full-text reports/articles were excluded if: no cases of VPDs reported (including review articles with no original data), data outside time range, different versions of same report/article, reports from hospital ships, or ships used to house displaced populations/refugees.

\subsection{Data Extraction and Analysis}

The quality of articles included in the review were assessed on the basis of completing the inclusion criteria. Specific questions and a data extraction sheet were used by the two researchers to independently and systematically review and extract the data from the publications. The data extraction sheet was pilot-tested on records/articles and then refined accordingly.

Duplicates and reports including data from prior to 1990 were excluded (Figure 1). Only references for which full text could be obtained and; therefore, analysis performed were included. For events with multiple reports, the original report was included and additional reports were only included if they contained additional information relevant for data extraction. For all included articles, full-text analysis was performed. 
We contacted authors from one paper for further information: Nieto Vera et al. Measles outbreak in Campo de Gibraltar, Cadiz, Spain, during the period February-July 2008 [22]. The number of laboratory-confirmed, epidemiologically-linked, and clinically compatible cases was clarified. As was the onset date of the last case and the number of hospitalizations.

\subsection{Ethical Approval}

This review concerns a review of already published material, and; therefore, ethical approval was not required. Moreover, data extracted from the EU SHIPSAN information system (https: //sis.shipsan.eu/) owned by the EU SHIPSAN ACT partnership who approved the use of data for the systematic review and had the tasks to conduct this literature review and to revise the "European Manual for Hygiene Standards and Communicable Disease Surveillance on Passenger Ships" in the framework of the EU SHIPSAN ACT joint action [16].

\section{Results}

\subsection{Reports Included in the Review}

Twenty-six articles/reports fulfilled the eligibility criteria (Figure 1). Additionally, eight records in the EU SHIPSAN ACT joint action information system and one personal communication reported cases or outbreaks of VPDs associated with ships were included in this review (Figure 1) [21,23]. The systematic review revealed 24 events including 17 outbreaks and seven single case events, which occurred between 1 January 1990 and 30 April 2019 on passenger, cargo, military, and work ships (Tables 1-3). Moreover, the systematic review analyzed data from five studies that presented results from review of ships' or of authorities' records and four studies reporting serological test results of seafarers.

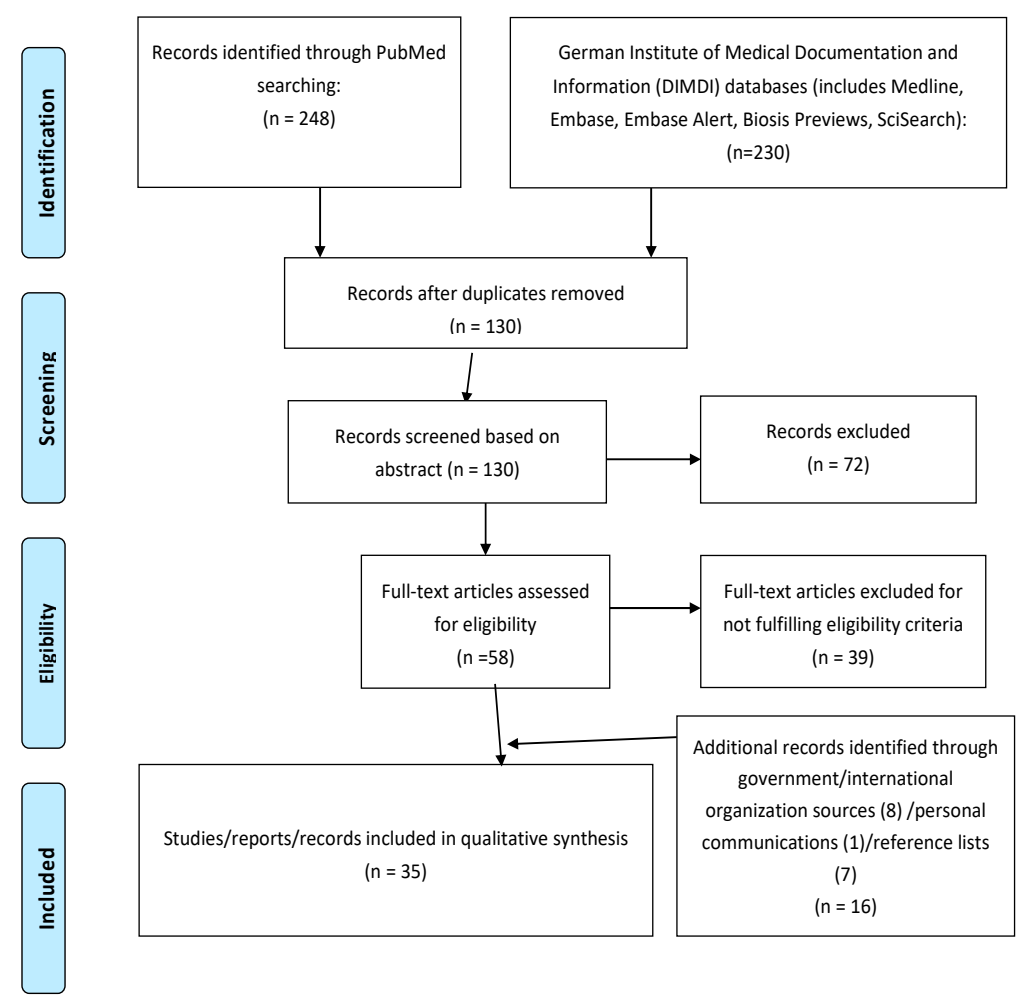

Figure 1. Flow chart of studies included in the review.

In total, 1795 cases (115 outbreaks, seven case reports) were identified, the majority were among crew $(1466 / 1795,81.7 \%)$ and were varicella cases $(1497,83.4 \%)$. The origin of crew cases was from 
sub-tropical countries in many reports. Measles (40 cases, $69 \%$ among crew), rubella $(47,88.7 \%$ crew), herpes zoster $(9,69.2 \% \mathrm{crew})$, and varicella cases $(1316,87.9 \% \mathrm{crew})$ were more frequent among crew. Mumps cases were equal among passengers and crew (22/22). Hepatitis A (73/92, 70.3\%), meningococcal meningitis $(16 / 29,44.8 \%)$, and pertussis $(9 / 9)$ were more frequent among passengers.

\subsection{Single Case Reports}

There were single case reports of each of diphtheria (in 1997), hepatitis A (in 2011), meningococcal meningitis case (in 2017), and varicella (in 2014 and 2018) from passenger ships, a meningococcal meningitis case from a military ship (in 2003) and varicella (in 2015) from cargo ships (Table 1) [21,24-27]. Six of the seven case reports were in crew with the exception being the diphtheria case, which was in a passenger [24].

Except from one death reported due to varicella [25], there were no other deaths reported. The case of meningitis (in 2017) and the diphtheria case were the only cases reported to be hospitalized ashore [21,24].

Regarding source of infection for the diphtheria case reported in a passenger, characterization of the diphtheria isolate found that the strain was indistinguishable from the predominant epidemic strain that was currently circulating in the countries of the former Union of Soviet Socialist Republics, providing evidence that the infection was likely acquired during the Baltic cruise [24].

Response measures were described in six out of the seven reports. In the three cases of varicella, isolation, case finding/active surveillance in crew and crew vaccination were applied and cases were reported to authorities [21,25]. Treatment, cleaning/disinfection and risk communication were described to be applied in response to one varicella case [21]. In response to the diphtheria case, diphtheria antitoxin and antibiotics were given to each case and close family, while contacts received antibiotic prophylaxis and low dose diphtheria vaccine boosters. Meningitis cases were isolated, in one case chemoprophylaxis was given to close contacts from the ship and contact tracing conducted [21,26].

\subsection{Outbreaks Reported (Events with More Than One Case Involved)}

\subsubsection{Characteristics of Outbreak Setting and Affected Population}

The review revealed 17 outbreaks of VPDs that have occurred world-wide based on the reports that fulfilled the eligibility criteria, between 1996 and 2019. Those outbreaks were varicella $(n=5)$, measles $(n=3)$, rubella $(n=3)$, a multi-pathogen varicella-measles-rubella outbreak $(n=1)$, hepatitis A $(n=3)$, meningitis $(n=1)$, and mumps $(n=1)$. Outbreaks were associated with passenger ships (13 cruise ships and one ferry), military (navy) ships $(n=2)$, and a cargo ship $(n=1)$ sailing world-wide (Table 1). Most cases were reported on ships associated with hepatitis A, varicella, rubella, and measles outbreaks, with 71, 63, 43, and 37 cases, respectively (Table 4). Two articles reported 262 secondary measles cases on land [22,28].

The duration of the majority of the outbreaks $(n=13)$ were protracted (over one month long) (Table 1) with the longest duration being for a varicella outbreak that spread between crew members of different ships (10 months) [23] and a measles outbreak that spread onto land (six months) [22,28]. Only one death was reported, during the meningitis 2012 outbreak (case fatality rate 25\%) [29]. Hospitalizations were reported in seven outbreaks $(7 / 17,41 \%)$ and the hospitalization rate varied between $8 \%$ to $100 \%$, being highest in the meningitis $2012(n=4 / 4,100 \%)$ and hepatitis A $(n=20 / 34$, $59 \%$ ) outbreaks (Table 1) $[29,30]$.

The majority of outbreaks involved crew members $(14 / 17,82 \%)$. Eleven outbreaks $(11 / 17,65 \%)$ affected only crew members and in two further measles outbreaks [22,28,31], crew were identified as the index cases leading to secondary crew cases, cases in passengers, and those on land [22,28]. One varicella outbreak in 2012 affected both crew and passengers and the index case was not reported [21]. In the three outbreaks of hepatitis A, all cases were reported in passengers on Nile cruises.

The total number of crew affected in outbreaks $(n=145)$ were almost double the number of passengers cases $(n=78)$ (Table 4). Crew attack rates, calculated using total crew as the denominator, ranged from $<1 \%$ to $6 \%$ (Table 1 ). It should be noted that the two highest attack rates $(4 \%$ and $6 \%)$ were derived from 
sero-surveys after confirmed rubella outbreaks, which included asymptomatic cases (approx. 50\% of cases in both studies); the highest attack $(6 \%)$ was for a rubella outbreak on a Navy ship where no control measures were documented and the outbreak only ended after the ship's return [3]. The mumps outbreak had a crew attack rate of $4 \%$, and a crew attack rate of $2.4 \%$ was calculated from the data available for the measles outbreak in 2014 [31]. Insufficient data were available for most varicella outbreaks to calculate the attack rate, but in two outbreaks it was less than $1 \%$ of crew (Table 1) [1,32]. In those outbreaks and events, which documented the nationality of crew from passenger ships $(n=10)$ (Table 1$)$, all noted crew from a range of countries (some ships had crew from over 130 countries), including a substantial proportion of crew originating from sub-tropical/tropical countries (Table 4). Insufficient data were reported to describe attack rates, the risk of secondary transmission to, or nationality of affected passengers.

\subsubsection{Secondary Cases on Land}

Two measles outbreaks linked to passenger ships are of particular interest as they reported a large number of cases and exemplify the risk of transmission of VPDs among crew, passengers and to others on land [22,28]. A measles outbreak in 2014, which started on a cruise ship in the western Mediterranean in 2014 [31], and another related to a fast ferry operating on the Algeciras (Spain)-Tangier (Morocco) route in 2008 [22], both led to extended outbreaks involving a substantial number of cases on land in Italy $(n=110)[28,31]$ and Spain $(n=152)$, respectively [22]. For the ferry outbreak in 2008, there were three index cases, two of which were crew members, which disembarked the ferry and led to a large outbreak in the county of Campo de Gibraltar in Spain [22]. In total 155 cases of measles were reported in the county over six months between February and July 2008, of which $88 \%(n=137)$ were laboratory confirmed. An incidence rate of 112.3 cases of measles per 105 population was reported in the Province of Algeciras which experienced most (83\%) of the cases.

For the 2014 measles outbreak on a cruise ship, as of 10 March 2014, there were 29 laboratory confirmed cases, $80 \%(n=23)$ of the cases were crew [3,31]. Twenty-three of the 968 crew $(2.4 \%)$ and six of approximately 3352 passengers $(0.2 \%)$ became infected with measles over a three-week period. In addition to sporadic contacts of primary cases becoming infected, two secondary outbreaks linked to passenger cases and involving extensive nosocomial transmission were reported on land [22,28]. One secondary outbreak occurred in Brindisi province, Puglia Region and involved 32 cases to 8 May 2014 [33]. The outbreak was spread within an emergency department of a hospital (including two health care worker cases) and then in the community to the fifth generation. The other secondary outbreak was even more extensive and led to 80 cases to July 2014 in Sardinia with transmission in families, work places and the hospital setting [28]. Nosocomial cases included health care workers $(n=15,19 \%)$ and patients infected while in the emergency department or hospital ward $(n=29,36 \%)$. In total, $45 \%$ (35/78) case-patients were hospitalized. In all these secondary outbreaks, most cases were young adults, but children including those $<2$ years old were also affected (Table 1 ).

\subsubsection{Vaccination History of Travelers}

Half of the outbreaks involving crew $(7 / 14,50 \%)$ documented the vaccination history or susceptibility rate of crew members and all found insufficient vaccination and/or documentation (Table 1). In all three rubella outbreaks, a substantial proportion of crew were found to have negative or no documentation of rubella vaccination or immunity $(75 \%, 81 \%$, and $96 \%$, respectively) $[3,34]$. In the measles 2014 outbreak, $85 \%$ of all crew and $21 / 24$ cases $(87.5 \%)$ had a negative or unknown vaccination history [28]. In the measles 2008 outbreak, $72 \%$ of cases had not been previously vaccinated [22]. In the mixed rash 2006 outbreak, only three crew members $(<1 \%)$ had proof of immunity (a vaccine record) to measles or rubella [1]. Three of nine (33\%) mumps cases had a mumps or measles-mumps-rubella (MMR) vaccine documented in the mumps 1992 outbreak [35]. For the three hepatitis A outbreaks involving only passengers, all reports documented that none of the cases had been vaccinated against hepatitis A [30,36,37]. 


\subsubsection{Source of Outbreaks}

Although most reports could determine the index case or cases of outbreaks, little data exists on the source of outbreaks or risk factors for transmission. The source of the three likely inter-linked hepatitis A outbreaks affecting only passengers was hypothesized to be a continuing common source linked to Nile river cruises $[30,36,37]$.

For the 12 outbreaks for which a crew member(s) was identified as the index case, only four outbreak reports discussed the likely exposure/source and believed the source of the outbreaks to have been exposure of crew on land, either before deployment or at one of the stops (Table 1).

In the rubella 1996 outbreak, three primary crew cases, all Germans, were thought to be infected off-ship and pre-deployment, as there became sick 8 to 10 days into deployment (within the incubation period), it could not be determined if the cases had the same source [3]. Sleeping in the ratings deck (basic rank, slept 40-80 per dorm and shared air-conditioning) was determined to be a risk factor for becoming infected with rubella in this outbreak, with sleeping conditions likely favoring transmission.

In the measles 2014 outbreak, a common exposure on board could not be found and the index crew member (origin not stated; $71 \%$ of crew from Asia) was thought likely infected at one of stops [31] or on board [28].

In the mixed rash outbreak in 2006, it was concluded that rubella was imported from the Philippines (Filipino crew member boarded nine days prior to onset), measles from the Ukraine (Ukrainian crew member boarded 13 days prior to onset) and varicella from unknown source country (possibly one of the ship stops as crew members boarded 22 days prior to onset) [1]. The authors also commented that close crew interactions outside the work environment played a role in the spread of the outbreak as there was sustained varicella transmission among crew members with different occupations.

In the meningitis 2012 outbreak, all cases were working in the ship's kitchen and originated from different countries in three different continents [29].

In two reports involving rubella, the potential risk of congenital rubella syndrome for passengers or crew of childbearing age was estimated. In one report, $33 \%$ of passenger responders were of childbearing age and $0.8 \%$ were pregnant [34]. In the other report, three crew members and $0.8 \%$ of passengers were pregnant [1].

\subsubsection{Response Measures}

All outbreak reports included reference to at least one response measure being used to control the outbreak (Table 1). In over half of the outbreaks, a report was sent to competent authorities (11/17, $65 \%)$ and isolation $(10 / 17,59 \%)$ were applied. Active surveillance or case finding in crew $(8 / 17,47 \%)$, risk communication with crew and/or passengers $(8 / 17,47 \%)$, and treatment of cases $(7 / 17,41 \%)$ were also commonly cited. Contact tracing $(4 / 17,23.5 \%)$, case finding/active surveillance in passengers or others $(5 / 17,29 \%)$, and cleaning/disinfection $(4 / 17,23.5 \%)$ were less frequently cited control measures. Only in one outbreak (measles 2014) was quarantine implemented and in two outbreaks (measles 2014 and mumps 1992) was disembarkation applied (Table 1) [3,31,35]. Vaccination was described as a post-prophylactic measure for crew in ten measles, varicella, and/or rubella outbreaks; and for passengers in two measles outbreaks. The number of vaccines administered were cited in four outbreaks: a total of 127/1020 (12.5\%) crew received vaccine in the measles 2011 outbreak which involved five crew cases [23], more than 400 crew on five different ships (total number of crew not stated) in the varicella 2008 outbreak that included 28 crew cases [23], 865/900 (96\%) crew in the rubella April to June 1997 outbreak with seven crew cases [34], and 1191/1200 (99\%) crew in the mixed rash outbreak 2006 with 16 crew cases [1]. No outbreak report described the use of immunoglobulin for post-exposure prophylaxis in either crew or passengers. However, it was described as used in close contacts on land in the extended measles outbreak in 2008 [22]. Costs of control measures to interrupt transmission were only cited in the mixed rash outbreak in 2006 that involved 16 crew cases on a passenger ship and was estimated at 67,000 USD for vaccinations, supplies, and health department staff time [1]. Specific guidelines were not cited as being applied or being recommended apart for in 
the measles 2014 outbreak, where in the absence of contact tracing guidelines specifically for ships, the Risk Assessment Guidance for Infectious Diseases transmitted on Aircraft (RAGIDA) guidelines for aircraft were recommend to be adapted [28].

\subsection{Events of VPDs Identified through Record Review Studies}

Record reviews identified a total of 1572 cases (1321 crew and 251 passengers). The four record reviews of surveillance data were undertaken between 2005 and 2015, for periods of six months, two years, and five years, the latter being for two reviews (Table 4). One review was of cruise ship medical logbooks from 34 cruise ships sailing into north America, 2009-2010 [38], one of cruise and cargo ship reports to Hamburg Port Health, Germany from world-wide cruises, November 2007 to April 2008 [39] and two of the US Centers for Disease Control and Prevention national database of cruise ships sailing in US waters, 2005-2009 [40,41].

These record reviews also found that the majority of cases reported were crew (78-100\% of cases); one US study found that only crew were responsible for being the index cases of outbreaks of varicella [38]. However, passenger cases and their contacts were reported in addition to crew members in two reviews (36 and 79 cases, respectively) (Table 4). Both US studies also found that a substantial proportion of varicella cases are associated with outbreaks on-board: One review found that $70 \%$ of crew cases $(n=66)$ were accountable to 18 clusters/outbreaks (defined as two or more epi-linked cases, two to nine cases per outbreak) and the other review found that $47.6 \%$ of crew and passenger cases $(n=89)$ were accountable to eight outbreaks (defined as five or more epi-linked cases, six to 26 cases per outbreak) $[38,40]$.

The first study found that the majority of cases were first-generation (68\%); however, there were also second and third-generation cases reported [40]. Two varicella record reviews recorded the age and sex of infected crew and found the majority to be male (100\% and $80 \%$, respectively) and the age range was 26-42 years [39] and 20-66 years (median 29 years) [40], respectively.

Only the German record review conducted in four ships addressed the possible source of the cases and identified non-immune employers as having been infected from an infected child $(n=1)$ or other crew members on board $(n=3)$ [39]. The US studies described control measures in-line with the published US-CDC Guidance' Guidance for Cruise Ships on Varicella (Chickenpox) Management' [14] and the German study in-line with the Port Health Centre recommendations (listed in the paper, no guideline referenced). Both recommendations included isolation of cases and contact tracing to allow for contact (post-exposure) vaccination. According to the authors, such recommendations were followed and were useful in controlling the outbreaks.

Records of reported deaths in the US revealed five deaths due to meningitis/meningococcal disease, three of them were among passengers [11].

\subsection{Evidence of VPDs Based on Serological Tests on Seafarers}

Three seroprevalence studies were undertaken in ships' crew for hepatitis A, B, and C in the 1990s and one for varicella in 2008 (Table 3). In addition, two of the rubella outbreak reports [3,34] and one varicella outbreak report [32] included seroprevalence studies. These studies found that $11 \%$ of cruise ship crew and $12 \%$ of navy ship crew were acutely infected or susceptible to rubella; and $13 \%$ [32] and 16.5\% [42] of crew were susceptible to varicella in two different studies, respectively. For the varicella outbreak it was estimated that "the ship population was two to three times more susceptible to varicella than an age-comparable US population" [32]. Hepatitis A susceptibility of ship crew was found to be between $85 \%$ to $100 \%$ and was positively associated with age in two studies (Table 3) [43-45]. Anti-hepatitis A virus (HAV) and anti-hepatitis B virus (HBV) positivity was found associated with those who had international deployment [43,44].

In the varicella 2008 study, the cost of antibody testing and vaccination was 7000 USD and the paper concludes that testing for antibodies followed by vaccination is a cost-effective method to prevent outbreaks on cruise ships and a recommended mandatory part of the pre-employment medical examination for Indian seafarers [42]. 
Table 1. Descriptive analysis of outbreak and case reports of vaccine-preventable diseases.

\begin{tabular}{|c|c|c|c|c|c|c|c|c|c|c|c|}
\hline Disease & $\begin{array}{l}\text { Dates, Number of } \\
\text { Affected Voyages } \\
\text { (Duration) }\end{array}$ & $\begin{array}{l}\text { Diagnosis/Case } \\
\text { Definition }\end{array}$ & $\begin{array}{l}\text { No. Cases } \\
\text { (Crew, Pax, } \\
\text { Other) }\end{array}$ & $\begin{array}{l}\text { Age, Sex, Nationality of } \\
\text { Cases }\end{array}$ & $\begin{array}{c}\text { No. } \\
\text { Hospitalizations } \\
\text { (H), } \\
\text { No. Deaths } \\
\end{array}$ & $\begin{array}{c}\text { Crew Attack } \\
\text { Rate } \\
\text { (of Susceptible) }\end{array}$ & $\begin{array}{l}\text { Place of Occurrence/ } \\
\text { Ship Type }\end{array}$ & Vaccination/Infection History & $\begin{array}{l}\text { Source/Risk } \\
\text { Factor }\end{array}$ & $\begin{array}{l}\text { Control Measures } \\
\text { Described * }\end{array}$ & Reference \\
\hline \multirow[t]{3}{*}{ Rubella } & $\begin{array}{l}2 \text { May-28 June 1996, } \\
1 \text { ( } 2 \text { months) }\end{array}$ & $\begin{array}{l}\text { Rubella IgM+or } \\
\text { IgG+ plus clinical } \\
\text { exanthema }\end{array}$ & $20(20,0,0)$ & $\begin{array}{l}\text { 18-33 years (mean 22.6); } \\
\text { all male, } \\
\text { German }\end{array}$ & $0(0 \%), 0$ & $6 \%$ crew $(57 \%)$ & $\begin{array}{l}\text { Unkn. ... } \\
\text { (ashore)/Military } \\
\text { (German Navy ship) }\end{array}$ & $\begin{array}{l}\text { A total of } 9 \%(n=27) \text { had } \\
\text { documentation of vaccination } \\
\text { status, } 81 \%(n=242) \text { had not } \\
\text { been vaccinated or did not know } \\
\text { status, } 36 \%(n=98) \text { of crew } \\
\text { indicated they had rubella in the } \\
\text { past- of which three became } \\
\text { cases; Susceptibility rate: } 12 \% \\
\text { (35/292) including infected }\end{array}$ & $\begin{array}{l}\text { Crew; } \\
\text { Hypothesized } \\
\text { source: off ship } \\
\text { pre-employment/ } \\
\text { Highest risk of } \\
\text { infection: sleeping } \\
\text { aboard ratings } \\
\text { deck }\end{array}$ & $\mathrm{A}, \mathrm{C}, \mathrm{E}$ & [3] \\
\hline & $\begin{array}{l}\text { April-June 1997, } \\
\text { multiple (3 months) }\end{array}$ & Rash illness & $7(7,0,0)$ & $\begin{array}{l}\text { Unkn., unkn. } \\
95 \% \text { not US-born }\end{array}$ & $0(0 \%), 0$ & $\begin{array}{l}0.8 \% \text { crew } \\
\text { (unkn) }\end{array}$ & $\begin{array}{l}\text { Florida (USA) to } \\
\text { Bahamas/Passenger } \\
\text { (cruise) }\end{array}$ & $\begin{array}{l}\text { Substantial proportion }(96 \%, \\
n=865) \text { of crew had no } \\
\text { documentation of rubella } \\
\text { vaccination or immunity }\end{array}$ & Unkn. & $\mathrm{B}, \mathrm{I}$ & [34] \\
\hline & $\begin{array}{l}\text { 30 May-2 August } \\
\text { 1997, multiple } \\
\text { (2 months) }\end{array}$ & $\begin{array}{l}\text { Rubella IgM+ or } \\
\text { clinical Rubella } \\
\text { plus epi-ink to } \\
\text { confirmed case }\end{array}$ & $16(16,0,0)$ & $\begin{array}{l}\text { Unkn., unkn. } \\
\text { 85\% not US born from } 50 \\
\text { countries }\end{array}$ & $0(0 \%), 0$ & $4.2 \%$ crew $(64 \%)$ & $\begin{array}{l}\text { Florida (USA) to } \\
\text { Bahamas/Passenger } \\
\text { (cruise) }\end{array}$ & $\begin{array}{l}75 \% \text { of crew had negative or } \\
\text { unknown vaccination history, } \\
\text { Susceptibility rate: } 11 \% \\
\text { (41//366) including infected }\end{array}$ & Unkn. & $\mathrm{B}, \mathrm{E}, \mathrm{F}, \mathrm{G}, \mathrm{I}$ & [34] \\
\hline \multirow{5}{*}{ Measles } & $\begin{array}{l}2 \text { February-18 July } \\
2008, \mathrm{~N} / \mathrm{A} \\
\text { (6 months) }\end{array}$ & $\begin{array}{l}\text { Confirmed or } \\
\text { epi-linked clinical } \\
\text { measles }\end{array}$ & $155(2,1,152)$ & $\begin{array}{l}\text { Age range: } 5 \text { months-41 } \\
\text { years }(38 \% \text { 20-29 years: } 19 \% \\
<2 \text { years); } 54 \% \text { male, unkn. }\end{array}$ & $13(8,4 \%), 0$ & $\mathrm{~N} / \mathrm{A}$ & $\begin{array}{c}\text { Algeciras } \\
\text { (Spain)-Tanger } \\
\text { (Morocco)/Passenger } \\
\text { (ferry) and Land } \\
\text { (Algeciras and } \\
\text { surrounds) }\end{array}$ & $\begin{array}{l}72.1 \% \text { of cases not previously } \\
\text { vaccinated }\end{array}$ & $\begin{array}{l}\text { Index cases were } 2 \\
\quad \text { crew and } 1 \\
\text { passenger }\end{array}$ & $\begin{array}{c}\mathrm{A}, \mathrm{F}, \mathrm{G}, \mathrm{N} \\
\text { (vaccination and Ig } \\
\text { to susceptible } \\
\text { contacts) }\end{array}$ & [22] \\
\hline & $\begin{array}{l}\text { 19-26 Aug 2011, } \\
\text { Various (8 days) }\end{array}$ & $\begin{array}{c}\text { Confirmed } \\
\text { measles }\end{array}$ & $5(5,0,0)$ & $\begin{array}{l}\text { Unkn., } 4 \text { male, } 1 \text { female, } \\
\text { Philippines: } 3 \text {, Honduras: } 1, \\
\text { Italy: } 1\end{array}$ & $0(0 \%), 0$ & $0.5 \%$ (unkn.) & $\begin{array}{l}\text { Spain, Malta, } \\
\text { Italy/Passenger }\end{array}$ & Unkn. & Unkn. & $\begin{array}{c}\text { A, B, C, D, E, F, G, } \\
\text { H, I, J }\end{array}$ & [21] \\
\hline & $\begin{array}{l}8 \text { February-July } \\
\text { 2014, N/A (6 } \\
\text { months) }\end{array}$ & $\begin{array}{l}\text { Epi-linked and } \\
\text { confirmed }\end{array}$ & $80(0,1,79)$ & $\begin{array}{l}\text { Median age } 26 \text { years (range: } \\
8 \text { months-55 years); } 50 \\
(62.5 \%) \text { female, N/A }\end{array}$ & $35 / 78(44.9 \%), 0$ & Unkn. & Sardinia, Italy/Land & $\begin{array}{l}74 / 76 \text { cases }(97.4 \%) \text { unvaccinated: } \\
2(2.6 \%) \text { with one dose of } \\
\text { measles vaccine }\end{array}$ & $\begin{array}{l}\text { Cruise ship } \\
\text { passenger }\end{array}$ & $\begin{array}{l}\mathrm{H}, \mathrm{G}, \mathrm{N} \text { (all } \\
\text { susceptible staff } \\
\text { invited for } \\
\text { vaccination) }\end{array}$ & [28] \\
\hline & $\begin{array}{l}20 \text { February- } 10 \\
\text { March 2014, } \\
1 \text { ( } 7 \text { days })\end{array}$ & $\begin{array}{l}\text { Clinical, epi- } \\
\text { linked and } \\
\text { confirmed }\end{array}$ & $29(23,6,0)$ & $\begin{array}{c}\text { 1-42 years (median 26); } 21 / 27 \\
\text { (78\%) male, Asia (71\%), } \\
\text { Europe (21\%), S. America } \\
\text { and Caribbean (7\%), Africa } \\
\text { (0.5\%) Median age 19 years } \\
\text { (range: } 0-39 \text { years); } 17(53 \%) \\
\text { female, } \\
\text { Italy: 6, India: 5, Philippines: } \\
\text { 3, Honduras: 2, Austria: 1, } \\
\text { Brazil: 1, Indonesia: } 1\end{array}$ & 10/27 (37\%), 0 & $2.4 \%$ (unkn.) & $\begin{array}{l}\text { Mediterranean Sea } \\
\text { (Italy, France, } \\
\text { Spain)/Passenger } \\
\text { (cruise) }\end{array}$ & $\begin{array}{l}\text { Vaccination status of } 24 \text { cases: } \\
\text { unkn. }(n=12), \text { unvaccinated } \\
(n=9) \text {, vaccinated with one to } \\
\text { two doses }(n=2, n=1) \text {. Of crew, } \\
142 \text { recalled vaccination and } \\
108 \text { history of measles }=150 / 968\end{array}$ & $\begin{array}{l}\text { Index case: crew } \\
\text { member(s): } \\
\text { infected during } \\
\text { cruise, possibly at } \\
\text { one of stops }\end{array}$ & $\begin{array}{c}\mathrm{A}, \mathrm{B}, \mathrm{E}, \mathrm{F}, \mathrm{G}, \mathrm{H}, \mathrm{I}, \mathrm{J} \\
\mathrm{K}, \mathrm{O}\end{array}$ & {$[3,31]$} \\
\hline & $\begin{array}{l}27 \text { February-May } \\
2014, \mathrm{~N} / \mathrm{A} \\
\text { (3 months) }\end{array}$ & $\begin{array}{l}\text { Clinical, epi- } \\
\text { linked and } \\
\text { confirmed }\end{array}$ & $32(0,1,31)$ & Unkn. & Unkn. & Unkn. & $\begin{array}{l}\text { Brindisi province, } \\
\text { Pugliai Region, } \\
\text { Italy/Land }\end{array}$ & $\begin{array}{l}\text { Unknown; } 1 / 32 \text { cases vaccinated } \\
\text { with one dose of MMR }\end{array}$ & $\begin{array}{l}\text { Cruise ship } \\
\text { passenger }\end{array}$ & $\begin{array}{c}\mathrm{H}, \mathrm{N} \text { (MMR } \\
\text { vaccination for } \\
2 \text { cases on land as } \\
\text { PEP and of } \\
\text { close contacts) }\end{array}$ & [33] \\
\hline
\end{tabular}


Table 1. Cont.

\begin{tabular}{|c|c|c|c|c|c|c|c|c|c|c|c|}
\hline Disease & $\begin{array}{l}\text { Dates, Number of } \\
\text { Affected Voyages } \\
\text { (Duration) }\end{array}$ & $\begin{array}{l}\text { Diagnosis/Case } \\
\text { Definition }\end{array}$ & $\begin{array}{l}\text { No. Cases } \\
\text { (Crew, Pax, } \\
\text { Other) }\end{array}$ & $\begin{array}{l}\text { Age, Sex, Nationality of } \\
\text { Cases }\end{array}$ & $\begin{array}{c}\text { No. } \\
\text { Hospitalizations } \\
\text { (HR), } \\
\text { No. Deaths }\end{array}$ & $\begin{array}{c}\text { Crew Attack } \\
\text { Rate } \\
\text { (of Susceptible) }\end{array}$ & $\begin{array}{l}\text { Place of Occurrence/ } \\
\text { Ship Type }\end{array}$ & Vaccination/Infection History & $\begin{array}{l}\text { Source/Risk } \\
\text { Factor }\end{array}$ & $\begin{array}{l}\text { Control Measures } \\
\text { Described * }\end{array}$ & Reference \\
\hline \multirow{9}{*}{ Varicella } & 1998, unkn. (unkn.) & $\begin{array}{l}\text { Clinical varicella } \\
\text { case }\end{array}$ & $3(3,0,0)$ & $\begin{array}{c}\text { Unkn., } \\
\text { Most foreign-borne, many } \\
\text { from tropical climates } \\
\end{array}$ & Unkn. & $<1 \%$ (unkn.) & $\begin{array}{l}\text { New York } \\
\text { Harbor/Passenger } \\
\text { (cruise) }\end{array}$ & $\begin{array}{l}\text { Susceptibility rate including } \\
\text { infected } 13 \% .\end{array}$ & Unkn. & $\mathrm{A}, \mathrm{C}, \mathrm{I}$ & [32] \\
\hline & $\begin{array}{l}28 \text { January-15 April } \\
2006 \text { Multiple } \\
\text { (7 days), (11 weeks) }\end{array}$ & Rash illness & $16(16,0,0)$ & $\begin{array}{l}\text { Index cases } 23 \text { and } 35 \text { years, } \\
\text { unkn., Ukraine and } \\
\text { Philippines. } \\
\text { Secondary cases: unkn., } \\
\text { unkn., majority from tropical } \\
\text { countries. } \\
\end{array}$ & $0(0 \%), 0$ & $1.3 \%$ (unkn.) & $\begin{array}{l}\text { Florida (US) to } \\
\text { Caribbean./Passenger } \\
\text { (cruise) }\end{array}$ & $\begin{array}{l}\text { Three crew members }(<1 \% \text { ) had } \\
\text { proof of immunity (vaccine } \\
\text { record) to measles and rubella }\end{array}$ & $\begin{array}{c}\text { All index cases } \\
\text { were crew } \\
\text { members; close } \\
\text { crew interactions } \\
\text { outside of work as } \\
\text { risk factor } \\
\end{array}$ & $\mathrm{A}, \mathrm{B}, \mathrm{E}, \mathrm{F}, \mathrm{G}, \mathrm{H}, \mathrm{I}$ & [1] \\
\hline & $\begin{array}{l}\text { February-November } \\
20085 \text { ships (unkn.), } \\
\text { (10 months) }\end{array}$ & $\begin{array}{l}\text { Clinical varicella } \\
\text { case }\end{array}$ & $28(28,0,0)$ & $\begin{array}{c}\text { Unkn., } \\
70 \% \text { crew from } \\
\text { subtropical/tropical countries }\end{array}$ & $0(0 \%), 0$ & Unkn. & $\begin{array}{l}\text { Mediterranean } \\
\text { Sea/Passenger }\end{array}$ & Unkn. & Unkn. & I & [23] \\
\hline & $\begin{array}{l}20 \text { February- } 30 \\
\text { March 2012,1 } \\
\text { (5 weeks) }\end{array}$ & $\begin{array}{l}\text { Clinical varicella } \\
\text { case }\end{array}$ & $3(2,1,0)$ & 4 years, male, unkn. & $0(0 \%), 0$ & $<1 \%$ (unkn.) & $\begin{array}{l}\text { UK, Spain, } \\
\text { Portugal/Passenger }\end{array}$ & Unkn. & Unkn. & $\mathrm{A}, \mathrm{B}, \mathrm{C}, \mathrm{D}, \mathrm{E}, \mathrm{G}, \mathrm{I}$ & [21] \\
\hline & $\begin{array}{l}29 \text { September-2 } \\
\text { October 2014, } \\
1 \text { (4 days) }\end{array}$ & $\begin{array}{l}\text { Clinical varicella } \\
\text { case }\end{array}$ & $1(1,0,0)$ & 27 years, male, unkn. & $0(0 \%), 0$ & Unkn. & $\begin{array}{c}\text { Malta, } \\
\text { Spain/Passenger }\end{array}$ & Unkn. & Unkn. & $\mathrm{A}, \mathrm{B}, \mathrm{C}, \mathrm{D}, \mathrm{E}, \mathrm{G}, \mathrm{I}$ & [21] \\
\hline & $\begin{array}{l}\text { 16 January-20 } \\
\text { February 2015 } \\
\text { Various (5 weeks) }\end{array}$ & $\begin{array}{l}\text { Clinical varicella } \\
\text { case }\end{array}$ & $5(5,0,0)$ & $\begin{array}{l}34 \text { years, male, unkn., } \\
\text { Indonesia }\end{array}$ & $0(0 \%), 0$ & Unkn. & $\begin{array}{c}\text { Spain, } \\
\text { Italy/Passenger }\end{array}$ & Unkn. & Unkn. & $\mathrm{A}, \mathrm{B}, \mathrm{C}, \mathrm{D}, \mathrm{E}, \mathrm{G}, \mathrm{I}$ & [21] \\
\hline & $\begin{array}{c}\text { 26-30 December } \\
\text { 2015, N/A (1 week) }\end{array}$ & $\begin{array}{c}\text { Varicella } \\
\text { pneumonia }\end{array}$ & $1(1,0,0)$ & 50 years, male, Indian & $\begin{array}{c}1 / 1(100 \%), 1 \\
\text { (cause of death } \\
\text { varicella } \\
\text { pneumonia) }\end{array}$ & 1/24 (unkn.) & Puerto Rico/Cargo & Unkn. & Unkn. & $\mathrm{A}, \mathrm{B}, \mathrm{E}, \mathrm{I}$ & [25] \\
\hline & $\begin{array}{l}\text { 12-21 September } \\
2016\end{array}$ & & $5(5,0,0)$ & Unkn. & $0(0 \%), 0$ & Unkn. & Belgium/Cargo ship & Unkn. & $\begin{array}{l}\text { New crew } \\
\text { members from the } \\
\text { Philippines } \\
\text { arrived } \\
\text { (22/08/2016) prior } \\
\text { to the outbreak or } \\
\text { by contacting } \\
\text { people in the port }\end{array}$ & $\mathrm{A}, \mathrm{B}, \mathrm{C}, \mathrm{E}, \mathrm{I}$ & [21] \\
\hline & February 2018,1 & $\begin{array}{l}\text { Clinically } \\
\text { diagnosed } \\
\text { varicella }\end{array}$ & $1(1,0,0)$ & Unkn., male, Philippines & $0(0 \%), 0$ & Unkn. & Spain/Container ship & Unkn. & Unkn. & $\mathrm{A}, \mathrm{B}, \mathrm{I}, \mathrm{E}$ & [21] \\
\hline
\end{tabular}


Table 1. Cont.

\begin{tabular}{|c|c|c|c|c|c|c|c|c|c|c|c|}
\hline Disease & $\begin{array}{l}\text { Dates, Number of } \\
\text { Affected Voyages } \\
\text { (Duration) }\end{array}$ & $\begin{array}{l}\text { Diagnosis/Case } \\
\text { Definition }\end{array}$ & $\begin{array}{l}\text { No. Cases } \\
\text { (Crew, Pax, } \\
\text { Other) }\end{array}$ & $\begin{array}{l}\text { Age, Sex, Nationality of } \\
\text { Cases }\end{array}$ & $\begin{array}{c}\text { No. } \\
\text { Hospitalizations } \\
\text { (HR), } \\
\text { No. Deaths } \\
\end{array}$ & $\begin{array}{c}\begin{array}{c}\text { Crew Attack } \\
\text { Rate } \\
\text { (of Susceptible) }\end{array} \\
\end{array}$ & $\begin{array}{l}\text { Place of Occurrence/ } \\
\text { Ship Type }\end{array}$ & Vaccination/Infection History & $\begin{array}{l}\text { Source/Risk } \\
\text { Factor }\end{array}$ & $\begin{array}{l}\text { Control Measures } \\
\text { Described }^{*}\end{array}$ & Reference \\
\hline \multirow{4}{*}{$\underset{A}{\text { Hepatitis }}$} & $\begin{array}{l}1 \text { September- } 30 \\
\text { November/2008, } 3 \\
\text { (3 months) }\end{array}$ & $\begin{array}{c}\text { Clinically } \\
\text { compatible case } \\
\text { with IgM } \\
\text { anti-HAV, disease } \\
\text { onset 1 Sept-30 } \\
\text { Nov and travel } \\
\text { history to Egypt } \\
\text { 2-6 weeks prior to } \\
\text { symptom onset } \\
\end{array}$ & $10(0,10,0)$ & $\begin{array}{c}\text { Median } 41 \text { years (range } \\
\text { 23-59); male to female ratio } \\
\text { 3:7, N/A }\end{array}$ & $1(10 \%), 0$ & Unkn. & $\begin{array}{l}\text { Nile river, } \\
\text { Belgium/Passenger } \\
\text { (river cruise }\end{array}$ & $\begin{array}{l}\text { No case vaccinated against } \\
\text { hepatitis A }\end{array}$ & $\begin{array}{l}\text { Continuing } \\
\text { common source, } \\
\text { most likely linked } \\
\text { to river cruise }\end{array}$ & B & [37] \\
\hline & $\begin{array}{l}\text { September-November } \\
\text { 2008, } 6 \text { (5-14 days), } \\
\text { (10 weeks) }\end{array}$ & $\begin{array}{c}\text { Hepatitis A cases } \\
\text { (symptoms + lab } \\
\text { confirmation of } \\
\text { acute infection) } \\
\text { with onset from } 1 \\
\text { Sept t2008 and } \\
\text { travel to Egypt } \\
15-50 \text { days prior to } \\
\text { symptom onset }\end{array}$ & $34(0,34,0)$ & $\begin{array}{l}\text { Mean age } 40.1 \text { years (range } \\
11-69) ; 59 \% \text { female, N/A }\end{array}$ & $20(59 \%), 0$ & Unkn. & $\begin{array}{l}\text { Nile river, } \\
\text { Germany/Passenger } \\
\text { (river cruise }\end{array}$ & $\begin{array}{c}\text { No case vaccinated against } \\
\text { hepatitis A }\end{array}$ & $\begin{array}{l}\text { Continuing } \\
\text { common source, } \\
\text { most likely linked } \\
\text { to river cruise }\end{array}$ & B & [30] \\
\hline & $\begin{array}{l}13 \text { September-28 } \\
\text { October 2009, } 5 \\
\text { ( } 9 \text { weeks) }\end{array}$ & $\begin{array}{l}\text { Person with IgM } \\
\text { anti-HAV who had } \\
\text { stayed in Egypt } \\
\text { 2-6 weeks prior to } \\
\text { symptom onset }\end{array}$ & $26(0,26,0)$ & $\begin{array}{l}\text { Mean age } 32.8 \text { years (range } \\
10-65) ; 50 \% \text { female, N/A }\end{array}$ & $17(65 \%), 0$ & Unkn. & $\begin{array}{l}\text { Nile river, } \\
\text { France/Passenger } \\
\text { (river cruise }\end{array}$ & $\begin{array}{c}\text { No case vaccinated against } \\
\text { hepatitis A }\end{array}$ & $\begin{array}{l}\text { Continuing } \\
\text { common source, } \\
\text { most likely linked } \\
\text { to river cruise }\end{array}$ & B & [36] \\
\hline & $\begin{array}{l}\text { January 2011, } 1 \\
\quad \text { (unkn.) }\end{array}$ & $\begin{array}{l}\text { Subgenotype IB } \\
\text { imported case }\end{array}$ & $1(1,0,0)$ & 28 years, male, Polish & 0,0 & Unkn. & $\begin{array}{c}\text { Argentina } \\
\text { (USA-South } \\
\text { American } \\
\text { Pacific-Atantic } \\
\text { Coast)/Passenger } \\
\text { (river cruise }\end{array}$ & $\begin{array}{l}\text { Self-report of one dose hepatitis } \\
\text { A vaccine in previous year }\end{array}$ & $\begin{array}{l}\text { Crew index case; } \\
\text { Possible risk factor: } \\
\text { consumption of } \\
\text { shellfish on land in } \\
\text { Mexico }\end{array}$ & $\mathrm{O}$ & [27] \\
\hline Mumps & $\begin{array}{l}\text { 15 June-13 August } \\
\text { 1992, } 1 \text { (unkn.) } \\
\text { ( } 2 \text { months) }\end{array}$ & Clinical mumps & $9(9,0,0)$ & $\begin{array}{l}\text { Mean } 24 \text { years (Range: } \\
18-35) \text {; unkn., unkn. }\end{array}$ & $2(22 \%), 0$ & $4 \%$ (unkn.) & $\begin{array}{c}\text { Western Pacific, } \\
\text { route: Japan to } \\
\text { Hawaii (US)/Military } \\
\text { (“US Reuben James" } \\
\text { Navy ship) }\end{array}$ & $\begin{array}{l}\text { Three cases had mumps or MMR } \\
\text { vaccine documented }\end{array}$ & Unkn. & $\mathrm{o}$ & [35] \\
\hline
\end{tabular}


Table 1. Cont.

\begin{tabular}{|c|c|c|c|c|c|c|c|c|c|c|c|}
\hline Disease & $\begin{array}{l}\text { Dates, Number of } \\
\text { Affected Voyages } \\
\text { (Duration) }\end{array}$ & $\begin{array}{l}\text { Diagnosis/Case } \\
\text { Definition }\end{array}$ & $\begin{array}{l}\text { No. Cases } \\
\text { (Crew, Pax, } \\
\text { Other) }\end{array}$ & $\begin{array}{l}\text { Age, Sex, Nationality of } \\
\text { Cases }\end{array}$ & $\begin{array}{c}\text { No. } \\
\text { Hospitalizations } \\
\text { (HR), } \\
\text { No. Deaths }\end{array}$ & $\begin{array}{c}\text { Crew Attack } \\
\text { Rate } \\
\text { (of Susceptible) }\end{array}$ & $\begin{array}{l}\text { Place of Occurrence/ } \\
\text { Ship Type }\end{array}$ & Vaccination/Infection History & $\begin{array}{l}\text { Source/Risk } \\
\text { Factor }\end{array}$ & $\begin{array}{l}\text { Control Measures } \\
\text { Described * }\end{array}$ & Reference \\
\hline Diphtheria & $\begin{array}{c}1997, \\
1 \text { (12 days) }\end{array}$ & $\begin{array}{c}\text { Confirmed } \\
\text { Corynebacterium } \\
\text { diphtheriae }\end{array}$ & $1(0,1,0)$ & 72 years, female, unkn. & $1(100 \%), 0$ & $\mathrm{~N} / \mathrm{A}$ & $\begin{array}{l}\text { Baltic sea/Passenger } \\
\text { (cruise) }\end{array}$ & Unkn. & $\begin{array}{l}\text { Travelling in } \\
\text { former } \\
\text { USSR/Baltic }\end{array}$ & $\begin{array}{c}\text { C, N (Diptheria } \\
\text { antitoxin and } \\
\text { antibiotics to case } \\
\text { and close family, } \\
\text { contacts received } \\
\text { antibiotic } \\
\text { prophylaxis and } \\
\text { low dose } \\
\text { diphtheria vaccine } \\
\text { boosters) }\end{array}$ & [24] \\
\hline \multirow{3}{*}{ Meningitis } & $\begin{array}{l}\text { May 2003, } \\
1 \text { (unkn.) }\end{array}$ & $\begin{array}{c}\text { Clinical } \\
\text { meningococcal } \\
\text { meningitis }\end{array}$ & $1(1,0,0)$ & 24 years, male, unkn. & 0,0 & Unkn. & $\begin{array}{c}\text { Mid Atlantic } \\
\text { ocean/Military } \\
\text { (aircraft carrier) }\end{array}$ & $\begin{array}{l}\text { Patient had received } \\
\text { meningococcal vacine three } \\
\text { years previously. }\end{array}$ & Unkn. & $\begin{array}{c}\mathrm{A}, \mathrm{C}, \mathrm{H}, \mathrm{N} \\
\text { (Chemoprophylaxis } \\
\text { to close contacts } \\
\text { from the ship) }\end{array}$ & [26] \\
\hline & $\begin{array}{c}\text { October 2012, } 1 \\
\text { (unkn.), (<1 month) }\end{array}$ & $\begin{array}{l}\text { Confirmed } \\
\text { Neisseria } \\
\text { meningitides }\end{array}$ & $4(4,0,0)$ & $\begin{array}{l}\text { Unkn., unkn., originated } \\
\text { from three different } \\
\text { continents }\end{array}$ & $\begin{array}{l}4(100 \%), 1 \\
(25 \%)\end{array}$ & Unkn. & $\begin{array}{l}\text { Italian } \\
\text { coast/Passenger } \\
\text { (cruise) }\end{array}$ & Unkn. & $\begin{array}{l}\text { All cases worked } \\
\text { in ship kitchen }\end{array}$ & $\begin{array}{c}\mathrm{B}, \mathrm{N} \\
\text { (Chemoprophylaxis } \\
\text { to all passengers } \\
\text { and crew on ship) }\end{array}$ & [29] \\
\hline & October 2017, 1 & Clinical meningitis & $1(1,0,0)$ & Unkn., female, unkn. & 1, unkn. & Unkn. & $\begin{array}{l}\text { Greece/Passenger } \\
\text { (cruise) }\end{array}$ & Unkn. & Unkn. & A, B, D, I, O & [21] \\
\hline
\end{tabular}


Table 2. Vaccine-preventable diseases identified through record review studies.

\begin{tabular}{|c|c|c|c|c|c|c|c|c|}
\hline Disease & $\begin{array}{l}\text { Dates (Number of } \\
\text { Affected Voyages, } \\
\text { Duration) }\end{array}$ & Diagnosis/Case Definition & $\begin{array}{l}\text { No. Cases (Crew, } \\
\text { Passenger, Other) }\end{array}$ & $\begin{array}{l}\text { Age (Years), Sex, Nationality of } \\
\text { Cases }\end{array}$ & $\begin{array}{l}\text { Population at Risk/Crew } \\
\text { Attack Rate (of } \\
\text { Susceptible) }\end{array}$ & $\begin{array}{c}\text { Place of } \\
\text { Occurrence/Ship Type }\end{array}$ & $\begin{array}{c}\text { Control } \\
\text { Measures } \\
\text { Described * }\end{array}$ & Reference \\
\hline \multirow{4}{*}{ Varicella } & $\begin{array}{l}\text { 2005-2009 (unkn., } \\
5 \text { years) }\end{array}$ & Clinical varicella case & $357(278,0,79)$ & $\begin{array}{l}\text { Crew: Median age } 29 \text { (range } \\
\text { 20-66), } 80 \% \text { male } \\
\text { Three-quarters of crew cases were } \\
\text { from Caribbean countries, } \\
\text { Indonesia, the Philippines, or India } \\
\text { Most cases in spring and winter }\end{array}$ & $\begin{array}{l}2305 \text { maritime illness } \\
\text { reports }\end{array}$ & $\begin{array}{l}\text { Sailing in US } \\
\text { waters/passenger }\end{array}$ & $\begin{array}{l}\text { A, B, C, E, F, G, } \\
\quad H, I, J\end{array}$ & [40] \\
\hline & $\begin{array}{c}\text { November } \\
\text { 2007-April } 2008 \\
\text { (4 ships, } 6 \text { months) }\end{array}$ & Clinical varicella case & $5(5,0,0)$ & $\begin{array}{l}26-42 \text { years, male } \\
\text { Majority from SE Asia and Eastern } \\
\text { European countries. Crew cases: } \\
\text { Indonesia (2), the Philippines (1), } \\
\text { Sri Lanka (2) Index: child } \\
\text { passenger on cruise (1) and crew } \\
\text { coming from home country during } \\
\text { incubation period (3) }\end{array}$ & $\begin{array}{l}13,377,28 \text {, and } 882 \mathrm{crew}, \\
\text { respectively }\end{array}$ & $\begin{array}{c}\text { Baltic } \\
\text { sea/Europe/Med/USA } \\
\text { and Caribbean/passenger } \\
\text { (2) cargo (1) work (feeder) } \\
\text { ship (1) }\end{array}$ & $\begin{array}{c}\text { A, B, C, E, F, G, } \\
\text { H, I, J } \\
\text { (instructed but } \\
\text { unclear what } \\
\text { was carried out) }\end{array}$ & [39] \\
\hline & $\begin{array}{l}\text { 2009-2010, } 34 \text { ships } \\
\text { ( } 2-25 \text { days, } 2 \text { years })\end{array}$ & Clinical varicella case (probable case) & $187(151,36,0)$ & $\begin{array}{l}\text { Unkn. }>130 \text { countries. } 26 \\
\text { countries for crew cases with } 58 \% \\
\text { from } 5 \text { sub-tropical or tropical } \\
\text { countries (the Philippines, } \\
\text { Indonesia, India, Jamaica, St. } \\
\text { Vincent and the Grenadines) }\end{array}$ & $\begin{array}{l}\text { 694-6300 passengers per } \\
\text { ship; } \\
400-2160 \text { crew per ship. } \\
\text { Crew attack rate (of } \\
\text { susceptible) } \\
\text { For crew clusters reported: } \\
\text { (i) } 29 / 860(3.4 \%) \\
\text { (ii) } 10 / 2400(0.4 \%) \\
\end{array}$ & World-wide/passenger & $\begin{array}{l}\text { A, B, C, E, F, G, } \\
\quad H, I, J\end{array}$ & [38] \\
\hline & $\begin{array}{c}\text { January } \\
\text { 2010-December } \\
\text { 2015, } 99 \text { outbreaks }\end{array}$ & Diagnosis of authority's medical officer & $\begin{array}{l}967 \text { (823 including } \\
758 \text { cruise ship crew, } \\
144,0)\end{array}$ & $\begin{array}{c}\text { Crew: 20-49: 394/399, 50+: 5/399, } \\
\text { Pax: <1: 3/99, } 1-9: 46 / 99,10-19: \\
\text { 18/99, 20-49: } 24 / 99 \\
50+: \text { : } 8 / 99 \\
\text { Male } 395 / 479 \text { crew } 60 / 106 \text { pax } \\
\text { Female } 44 / 479 \text { crew } 46 / 106 \text { pax } \\
\text { Indonesia }(21.7 \%, 80 / 369), \\
\text { Philippines }(17.6 \%, 65 / 369) \text {, or } \\
\text { India }(17.3 \%, 64 / 369)\end{array}$ & Unknown & $\begin{array}{l}\text { USA/63 cargo ships, } 900 \\
\text { cruise ships }\end{array}$ & $\mathrm{A}, \mathrm{B}, \mathrm{C}, \mathrm{H}, \mathrm{I}, \mathrm{J}, \mathrm{O}$ & [41] \\
\hline Herpes zoster & $\begin{array}{l}\text { January } \\
\text { 2010-December } \\
2015\end{array}$ & Diagnosis of authority's medical officer & $\begin{array}{c}13(9 \text { including } 7 \\
\text { cruise ship crew, } 4,0)\end{array}$ & Unkn. & Unkn. & $\begin{array}{l}\text { USA } / 2 \text { cargo ships, } 11 \\
\text { cruise ships }\end{array}$ & Unkn. & [41] \\
\hline Mumps & $\begin{array}{l}\text { January } \\
\text { 2010-December } \\
2014\end{array}$ & $\begin{array}{l}\text { Presumptive or final diagnoses based on the } \\
\text { information available from healthcare } \\
\text { facilities, health departments, medical } \\
\text { examiners, or laboratories, when available, } \\
\text { and review by a quarantine medical officer }\end{array}$ & $35(13,22,0)$ & Unkn. & Unkn. & Unkn. & Unkn. & [11] \\
\hline
\end{tabular}


Table 2. Cont.

\begin{tabular}{|c|c|c|c|c|c|c|c|c|}
\hline Disease & $\begin{array}{c}\text { Dates (Number of } \\
\text { Affected Voyages, } \\
\text { Duration) }\end{array}$ & Diagnosis/Case Definition & $\begin{array}{l}\text { No. Cases (Crew, } \\
\text { Passenger, Other) }\end{array}$ & $\begin{array}{l}\text { Age (Years), Sex, Nationality of } \\
\text { Cases }\end{array}$ & $\begin{array}{c}\text { Population at Risk/Crew } \\
\text { Attack Rate (of } \\
\text { Susceptible) }\end{array}$ & $\begin{array}{c}\text { Place of } \\
\text { Occurrence/Ship Type }\end{array}$ & $\begin{array}{c}\text { Control } \\
\text { Measures } \\
\text { Described * }\end{array}$ & Reference \\
\hline $\begin{array}{l}\text { Meningitis/ } \\
\text { meningococcal } \\
\text { disease }\end{array}$ & $\begin{array}{c}\text { January } \\
\text { 2010-December } \\
2014\end{array}$ & $\begin{array}{l}\text { Presumptive or final diagnoses based on the } \\
\text { information available from healthcare } \\
\text { facilities, health departments, medical } \\
\text { examiners, or laboratories, when available, } \\
\text { and review by a quarantine medical officer }\end{array}$ & $25(9,16,0)$ & Unkn. & Unkn. & Unkn. & Unkn. & [11] \\
\hline Hepatitis A & $\begin{array}{l}\text { January } \\
\text { 2010-December } \\
2014\end{array}$ & $\begin{array}{l}\text { Presumptive or final diagnoses based on the } \\
\text { information available from healthcare } \\
\text { facilities, health departments, medical } \\
\text { examiners, or laboratories, when available, } \\
\text { and review by a quarantine medical officer }\end{array}$ & $22(19,3,0)$ & Unkn. & Unkn. & Unkn. & Unkn. & [11] \\
\hline Measles & $\begin{array}{l}\text { January } \\
\text { 2010-December } \\
2014\end{array}$ & $\begin{array}{l}\text { Any probable or confirmed measles case } \\
\text { determined to be contagious during travel. } \\
\text { Presumptive or final diagnoses based on the } \\
\text { information available from healthcare } \\
\text { facilities, health departments, medical } \\
\text { examiners, or laboratories, when available, } \\
\text { and review by a quarantine medical officer }\end{array}$ & $21(10,11)$ & Unkn. & Unkn. & Unkn. & Unkn. & [11] \\
\hline Rubella & $\begin{array}{l}\text { January } \\
\text { 2010-December } \\
2014\end{array}$ & $\begin{array}{l}\text { Presumptive or final diagnoses based on the } \\
\text { information available from healthcare } \\
\text { facilities, health departments, medical } \\
\text { examiners, or laboratories, when available, } \\
\text { and review by a quarantine medical officer }\end{array}$ & $10(4,6)$ & Unkn. & Unkn. & Unkn. & Unkn. & [11] \\
\hline Pertussis & $\begin{array}{l}\text { January } \\
\text { 2010-December } \\
2014\end{array}$ & $\begin{array}{l}\text { Presumptive or final diagnoses based on the } \\
\text { information available from healthcare } \\
\text { facilities, health departments, medical } \\
\text { examiners, or laboratories, when available, } \\
\text { and review by a quarantine medical officer }\end{array}$ & $9(0,9)$ & Unkn. & Unkn. & Unkn. & Unkn. & [11] \\
\hline
\end{tabular}


Table 3. Seroprevalence studies.

\begin{tabular}{|c|c|c|c|c|c|c|c|c|c|c|}
\hline $\begin{array}{c}\text { Disease, Study } \\
\text { Duration [Reference] }\end{array}$ & $\begin{array}{l}\text { Study Date } \\
\text { (Duration) }\end{array}$ & Study Sample & $\begin{array}{l}\text { Serological } \\
\text { Markers * }\end{array}$ & $\begin{array}{c}\text { No. Study } \\
\text { Subjects (Age, } \\
\text { Sex, Nationality }\end{array}$ & Seropositivity & $\begin{array}{l}\text { Seropositivity } \\
\text { By Age }\end{array}$ & $\begin{array}{l}\text { Seropositivity } \\
\text { by Nationality }\end{array}$ & Susceptibility & $\begin{array}{l}\text { Vaccination/Infection } \\
\text { History }\end{array}$ & Risk Factors \\
\hline $\begin{array}{c}\text { Hepatitis Study/ } \\
\text { 1989-1991 } \\
{[44]}\end{array}$ & $\begin{array}{c}1989-1991 \\
\text { (3 years) }\end{array}$ & $\begin{array}{l}\text { US military } \\
\text { personnel } \\
\text { scheduled for } \\
\text { deployment on } \\
11 \text { US Navy ships }\end{array}$ & $\begin{array}{c}\text { Anti-HAV+, } \\
\text { Anti-HBc+, } \\
\text { Anti-HBsAg+ } \\
\text { Anti-HDV, } \\
\text { Anti-HCV+ }\end{array}$ & $\begin{array}{l}2072 \text { (male, mean } \\
24 \text { years; } 72 \% \\
\text { white) }\end{array}$ & $\begin{array}{c}\text { Anti-HAV+ } \\
210(10.1 \%) ; \\
\text { Anti-HBc+ } \\
76(3.7 \%) ; \\
\text { Anti-HCV+ } \\
9(0.4 \%)\end{array}$ & $\begin{array}{c}\text { Increasing with } \\
\text { age: } \mathrm{HAV}+7.8 \% \\
\text { in } 18-24 \text { years; } \\
28.7 \% \text { in }>34 \\
\text { years } \\
\text { Anti-HBc+: } 2.2 \% \\
\text { in } 18-24 \text { yo; } 7.2 \% \\
\text { in } 25-34 \text { years; } \\
8.3 \% \text { in }>34 \text { years }\end{array}$ & $\begin{array}{l}\text { For country of } \\
\text { birth: } \\
\text { Anti-HAV+ } 8 \% \\
\text { for USA and } \\
39.3 \% \text { for foreign; } \\
\text { HBV+ for } 3.2 \% \\
\text { USA } 10.7 \% \text { for } \\
\text { foreign }\end{array}$ & HAV: $90 \%$ & $\begin{array}{l}28 \text { subjects reported } \\
\text { a history of acute } \\
\text { hepatitis (50\% were } \\
\text { anti HAV+ } \\
\text { compared to } 9.6 \% \\
\text { without a history) }\end{array}$ & $\begin{array}{c}\text { Anti-HAV positivity associated } \\
\text { with age, non-white racial/ethnic } \\
\text { group, born outside US and prior } \\
\text { Caribbean deployment for }<1 \text { year. } \\
\text { Anti-HBV with black and } \\
\text { Philippino race, foreign birth, a } \\
\text { history of STD and South } \\
\text { Pacific/IIdian Ocean deployment } \\
\text { for }<12 \text { months, and S Pacific or } \\
\text { Med duty for }>1 \text { year }\end{array}$ \\
\hline $\begin{array}{c}\text { Hepatitis Study/1993 } \\
{[43]}\end{array}$ & $\begin{array}{l}\text { April-December } \\
1993 \text { (9 months) }\end{array}$ & $\begin{array}{c}\text { Seamen } \\
\text { attending five } \\
\text { clinics } \\
\text { performing } \\
\text { mandatory } \\
\text { health } \\
\text { examinations of } \\
\text { seamen in } \\
\text { Denmark }\end{array}$ & $\begin{array}{c}\text { Anti-HAV+, } \\
\text { Anti-HBc+, } \\
\text { Anti-HBAg+, } \\
\text { Anti-HCV+ }\end{array}$ & $\begin{array}{c}515 \text { ( } 86 \% \text { male; } \\
94 \% \\
\text { Scandinavian) }\end{array}$ & $\begin{array}{c}\text { Anti-HAV+ } \\
79(15.3 \%) ; \\
\text { Anti-HBc+ } \\
47(9.1 \%) ; \\
\text { Anti-HCV+ } \\
6(1.2 \%)\end{array}$ & $\begin{array}{c}\text { Increasing with } \\
\text { age: } \mathrm{HAV}+0.3 \% \\
\text { in }<40 ; 71 \% \text { in } \\
60-69 \text { years. } \\
\mathrm{HBV}+: 2.7 \% \text { in } \\
<40 ; 35.7 \% \text { in }>60\end{array}$ & $\begin{array}{c}\text { For origin: } \\
\text { Anti-HAV+ } \\
12.8 \% \text { for } \\
\text { Scandinavian } \\
\text { and 52.4\% for } \\
\text { foreign; } \\
\text { HBV+ } 7.9 \% \text { for } \\
\text { Scandinavian, } \\
28.5 \% \text { for foreign }\end{array}$ & HAV: $85 \%$ & $\begin{array}{c}1 \mathrm{HAV}+\text { case } \\
\text { previously had HAV } \\
\text { vaccination }\end{array}$ & $\begin{array}{l}\text { Anti-HAV and HBV positivity } \\
\text { associated with age. HAV } \\
\text { seroprevalence highest among } \\
\text { those who sailed in international } \\
\text { trade (outside USA and Europe) }\end{array}$ \\
\hline $\begin{array}{c}\text { Hepatitis Study/1998 } \\
{[45]}\end{array}$ & $\begin{array}{c}\text { February-July } \\
1998 \\
\text { (6 months) }\end{array}$ & $\begin{array}{l}\text { Personnel from a } \\
\text { Greek warship }\end{array}$ & $\begin{array}{c}\text { Anti-HAV+, } \\
\text { Anti-HBsAg+ } \\
\text { Anti-HBc+, } \\
\text { Anti-HBs+, } \\
\text { Anti-HCV+ }\end{array}$ & $\begin{array}{l}263 ; \text { (male, mean } \\
\text { age } 24.4 \text { years) }\end{array}$ & $\begin{array}{c}\text { Anti-HAV+ } \\
0(0 \%) ; \\
\text { Anti-HBsAg+ } \\
3(1.1 \%) ; \\
\text { Anti-HBc+, } \\
4(1.5 \%) \\
\text { Anti-HBs+ } \\
45(17.1 \%) ; \\
\text { Anti-HCV+ } \\
1(0.4 \%) \\
\end{array}$ & Unkn. & Unkn. & HAV: $100 \%$ & $\begin{array}{l}23 \text { subjects reported } \\
\text { vaccination against } \\
\text { Hepatitis B (three } \\
\text { doses by } 14 \text { subjects) }\end{array}$ & Unkn. \\
\hline $\begin{array}{c}\text { Varicella Study/2008 } \\
{[\text { [42] }}\end{array}$ & $\begin{array}{l}\text { 1-23 December } \\
2008 \text { (3 weeks) }\end{array}$ & $\begin{array}{l}\text { Cruise ship crew } \\
\text { members } \\
\text { undergoing } \\
\text { pre-employment } \\
\text { medical exam in } \\
\text { Mumbai and Goa }\end{array}$ & $\begin{array}{l}\text { VZV IgM+ and } \\
\operatorname{IgG}+\end{array}$ & $\begin{array}{l}121 \text { (male, } 21-42 \\
\text { years, } 100 \% \\
\text { Indian) }\end{array}$ & $\begin{array}{c}100(82.7 \%) \text { IgG+ } \\
0(0 \%) \text { IgM+ }\end{array}$ & Unkn. & Unkn. & $\begin{array}{c}16.5 \% \\
\text { susceptibility }\end{array}$ & $\begin{array}{c}60 \% \text { IgG pos. crew } \\
\text { could remember } \\
\text { disease or vaccine } \\
\text { history }\end{array}$ & Unkn. \\
\hline
\end{tabular}

* anti-HAV: antibodies to hepatitis A virus, anti-HBc: antibodies to hepatitis B core antigen, anti-HCV: antibodies to hepatitis C virus, Anti-HBsAg: antibodies to hepatitis B surface antigen,

VZV: Varicella Zoster Virus, IgM: immunoglobulin M, IgG: immunoglobulin G, Unkn.: unknown, STD: Sexually Transmitted Disease. 
Table 4. Characteristics of cases from reported outbreaks, case reports, and record reviews (results from seroprevalence studies not included).

\begin{tabular}{|c|c|c|c|c|c|c|c|c|c|c|}
\hline \multirow{2}{*}{ Disease } & \multirow{2}{*}{$\begin{array}{c}\text { No. Clusters/ } \\
\text { Outbreaks > } 1 \text { Cases }\end{array}$} & \multicolumn{2}{|c|}{ No. Crew Cases } & \multicolumn{2}{|c|}{ No. Pax Cases } & \multirow{2}{*}{$\begin{array}{c}\text { Total Crew, } \\
\text { Pax/Total Cases } \\
n=1795(\%)\end{array}$} & \multirow{2}{*}{$\begin{array}{l}\text { No. Other } \\
\text { Cases }\end{array}$} & \multirow{2}{*}{ Male/Female } & \multirow{2}{*}{ Origin of Cases } & \multirow{2}{*}{ Ship Type } \\
\hline & & Out. Rep. $\ddagger^{\ddagger}$ & Rev.Rec. ${ }^{\infty}$ & Out. Rep. & Rev. Rec & & & & & \\
\hline Measles & 3 & 30 & 10 & 7 & 11 & $40,18 / 58(3,2)$ & $262 *$ & $25 / 7$ & $\begin{array}{c}\text { Asia, Europe, S. America, } \\
\text { Caribbean, Africa, Italy, India, } \\
\text { Philippines, Honduras, } \\
\text { Austria, Brazil, } \\
\text { Indonesia, unkn. }\end{array}$ & 1 ferry, 2 cruise \\
\hline Rubella & 3 & 43 & 4 & - & 6 & $47,6 / 53(3,0)$ & 0 & 20/- & German, unkn. & $\begin{array}{l}2 \text { cruise, } 1 \\
\text { military }\end{array}$ \\
\hline Hepatitis A & 3 & - & 19 & 70 & 3 & $19,73 / 92(5,1)$ & 0 & $31 / 40$ & Polish, unkn. & $\begin{array}{l}4 \text { river cruise } \\
\text { ships }\end{array}$ \\
\hline $\begin{array}{l}\text { Meningococcal } \\
\text { meningitis }\end{array}$ & 1 & 4 & 9 & - & 16 & $13,16 / 29(1,6)$ & 0 & $1 / 1$ & unkn. & $\begin{array}{l}2 \text { cruise, } 1 \\
\text { military }\end{array}$ \\
\hline Mumps & 1 & 9 & 13 & - & 22 & $22,22 / 44(2,5)$ & 0 & $-1-$ & unkn. & 1 military \\
\hline Pertussis & unkn $\sqrt{ }$. & - & - & - & 9 & $0,9 / 9(0,5)$ & 0 & $-1-$ & unkn. & - \\
\hline $\begin{array}{l}\text { Herpes } \\
\text { zoster }\end{array}$ & unkn. & - & 9 & - & 4 & $9,4 / 13(0,7)$ & 0 & $-/-$ & unkn. & $\begin{array}{l}11 \text { cruise, } 2 \\
\text { cargo }\end{array}$ \\
\hline Varicella & 104 & 59 & 1257 & 1 & 180 & $\begin{array}{c}1316,181 / 1497 \\
(83,4)\end{array}$ & $79^{+}$ & $687 / 130$ & $\begin{array}{c}\text { Indonesia, India, Philippines, } \\
\text { SE Asia, Eastern European } \\
\text { countries, Sri Lanka, Caribbean } \\
\text { countries, unkn. }\end{array}$ & $\begin{array}{l}909 \text { cruise, } 69 \\
\text { cargo }\end{array}$ \\
\hline Total & 115 & 145 & 1321 & 78 & 251 & $223,1572 / 1795$ & 341 & $764 / 179$ & & 1006 \\
\hline
\end{tabular}




\section{Discussion}

The literature review showed that despite past and current evidence for VPDS cases and outbreaks on ships, cross-border VPDs transmission and maritime occupational risks, documented pre-employment examination of immune status, vaccination of seafarers, and travel advice to passenger are not routinely conducted.

Most outbreaks and cases of VPDs identified were among crew members of cruise ships and were varicella cases. Furthermore, the majority of outbreaks identified a crew member as the index case and the origin of crew cases was from sub-tropical countries in many reports. Immune status of crew members varies depending on the country of origin. Crew originating from countries with low immunization rates and/or ongoing disease transmission could be index cases of outbreaks on board ships [46]. Few data were identified in the literature about crew susceptibility. Seroprevalence studies or surveys as part of outbreak response demonstrated approximately $13 \%$ to $16 \%$ susceptibility of cruise ships' crew to varicella [32,42], 11\% to rubella [3,34], and high susceptibility of merchant seamen to HAV (85\%) [43]. VPDs such as varicella and measles can cause serious complications to adults and an outbreak could affect the normal ship operation especially on ships with a small number of crew sailing on long voyages [47]. In cruise ships, crew members could potentially expose large number of passengers to pathogens depending on their duties and position such as staff in medical facilities and beauty salons, waiters, bartenders, receptionists, and food handlers.

The International Medical Guide for Ships (IMGS) recommends immunization of susceptible crew members after diagnosis of the first case of varicella on board a ship, as a measure to prevent an outbreak, but not as a routine precautionary measure. In the US, varicella is the most frequent VPDs reported on ships and one death of varicella pneumonia was reported in 2015 [11,25]. As a regular pre-employment condition, IMGS requires immunization for diphtheria and tetanus for every seagoing person, while for hepatitis A and hepatitis B for any crew member assigned to medical care duties [47]. For all other crew, IMGS suggests immunization against hepatitis A and hepatitis B as a "wise precaution". Vaccinations for diseases including cholera, influenza, Japanese encephalitis, meningococcal disease, poliomyelitis, rabies, typhoid fever, and yellow fever would depend on ship destinations and type of freight carried according to IMGS [47]. According to the WHO (World Health Organization) Handbook for Inspection of Ships and Issuance of Ship Sanitation Certificates, inspectors when inspecting ships to issue Ship Sanitation Certificates should ensure that a list of crew members taking care of children is available, indicating the vaccines they have received [48].The Maritime Labour Convention (MLC) of the International Labour Organization (ILO) provides that competent authorities adopt regulations to prevent diseases of seafarers on board [49]. Such regulations can include specific vaccinations and assessment of immune status as a condition for employment of seafarers.

The literature review provided evidence for outbreaks of varicella, measles, rubella, mumps, hepatitis A and meningococcal meningitis in crew. Cruise ships should gain adequate proof of immunity from crew members and provide vaccination to those with inadequate proof, after considering contraindications. In addition to the recommended vaccinations in the IMGS, we recommend vaccination for measles, mumps, varicella, and rubella to be considered in the pre-employment policy of seafarers, rather than as a response measure to prevent outbreaks after the first case occurred. Outbreak control measures and medical evacuations at sea are very resource intensive $[1,38,46]$, so prevention policies involving vaccinations would be more cost effective than control.

The literature review revealed outbreaks of measles, rubella, herpes zoster, varicella, mumps, hepatitis A, meningococcal meningitis, and pertussis among passengers of cruise ships. Passengers need to be advised about vaccinations before travel, including for measles, mumps, varicella, and rubella $[31,34,40,42]$. Especially travelers of at-risk groups should be vaccinated according to instructions from family doctors and in sufficient time to develop immunity before boarding ships. Before travelling, pregnant women should check for immunity for infectious disease and update immunizations as needed [50]. Two authors, during investigations of rubella and varicella outbreaks, found pregnant 
crew members and passengers among the potentially exposed on board ships [1,34]. Vaccination of crew can protect pregnant passengers and crew from exposure to VPDs that can affect pregnancy.

Global data on measles, which has been characterized as the most contagious disease, demonstrate a significant increase in the last two years and this trend continues into the first quarter of 2019, according to WHO [51]. Based on reports received by 30 EU/EEA Member States, ECDC has reported that there is an ongoing large measles outbreak involving more than 44 thousand cases in the last three years [52]. This global increase in measles outbreaks could affect maritime transport since index cases are exposed ashore [3,22,31]. Outbreaks on ships can result in cross-border disease transmission, as reported in two measles outbreaks where secondary cases occurred on land in 2014 [3,31,33]. Preparedness for response, as well as prevention strategies, are advised to be adopted by shipping companies. In case of hospitalizations and laboratory diagnosis conducted ashore, communication of public health information from ship doctors to port health authorities and health care services on land and vice-versa are important to effectively and timely apply control measures [46]. The European Commission new provisional edition of the document for a Regulation on the European Maritime Single Window, suggest the establishment of a ship sanitation database for storing Maritime Declaration of Health, which is expected to facilitate risk assessment and enhance communication between port health authorities and ships [53].

The objectives of this review were achieved by collecting evidence mainly from published data. It is possible that most cases and outbreaks are not published in the scientific literature. The majority of cases were varicella cases collected by the US reporting system. Data collected in this review are mainly from US and Europe. In Europe, even if there is an information system available to MS to record cases and public health measures information, it is not systematically used in all EU MS. Moreover, it is possible that cases or outbreaks have been reported to other non-EU countries, but those were not considered in our study. It is unknown how many cases and outbreaks are not reported to competent authorities.

The consortium of the EU SHIPSAN ACT joint action conducted the current literature review in order to use its results to create a chapter for the prevention and control of VPDs in the European Manual for Communicable Disease Surveillance and Hygiene Standards on Passenger Ships [16]. This manual provides guidance to shipping companies and to port health authorities about pre-embarkation and everyday preventive measures, as well as in response to cases and outbreaks. It suggests that seafarers should maintain written proof of vaccination to demonstrate when needed during pre-employment medical examinations and during voyages. Shipping companies should perform checks of immune status when needed, conduct occupational risk assessments, administer vaccinations for varicella, measles, and rubella in agreement with seafarers and keep up-to-date records of their staff [16]. Passengers should seek travel advice before cruising. Surveillance for early detection of VPD cases and isolation of cases, contact tracing and reporting to competent authorities are also important measures. Standard operating procedures should be available to port health authorities' contingency plans on how to respond to events of VPDs. Shipping companies' prevention and control policies should also include standard operating procedures about response measures to VPD events.

Author Contributions: Conceptualization, C.H. and EU SHIPSAN ACT joint action partnership; methodology and review conduct, V.A.M., H.L.W. and C.H.; resources, EU SHIPSAN ACT joint action partnership.

Funding: This research was funded by: EU SHIPSAN ACT Joint Action financed by the Second Programme of Community action in the Field of Health 2008-2013, grant number [20122103], Start date: 01/02/2013, End date: 01/11/2016, Duration: 45 month(s), Current status: Finalized.

Conflicts of Interest: The authors declare no conflicts of interest. 


\section{References}

1. Mitruka, K.; Felsen, C.B.; Tomianovic, D.; Inman, B.; Street, K.; Yambor, P.; Reef, S.E. Measles, rubella, and varicella among the crew of a cruise ship sailing from Florida, United States, 2006. J. Travel Med. 2012, 19, 233-237. [CrossRef] [PubMed]

2. Public Health Agency Canada. Canada Communicable Disease Report (CCDR); Beaudoin, N., Ed.; Public Health Agency Canada: Ottawa, ON, Canada, 2005; pp. 1-17.

3. Ziebold, C.; Hassenpflug, B.; Wegner-Bröse, H.; Wegner, K.; Schmitt, H.J. An outbreak of rubella aboard a ship of the German Navy. Infection 2003, 31, 136-142. [PubMed]

4. EUROSTAT. Maritime Ports Freight and Passenger Statistics. Available online: https: //ec.europa.eu/eurostat/statistics-explained/index.php/Maritime_ports_freight_and_passenger_statistics\# Slight_increase_in_seaborne_goods_and_passengers_in_EU_ports (accessed on 7 May 2019).

5. Cruise Line International Association. Clia 2017 Annual Report; CLIA: Washington, DC, USA, 2017.

6. International Chamber of Shipping. International Chamber of Shipping. Shaping the Future of Shipping 2019. Available online: http://www.ics-shipping.org/shipping-facts/shipping-and-world-trade/global-supply-anddemand-for-seafarers (accessed on 26 July 2019).

7. Hadjichristodoulou, C.; Mouchtouri, V.A.; Guglielmetti, P.; Lemos, C.M.; Nichols, G.; Paux, T.; Schlaich, C.; Cornejo, M.D.; Martinez, C.V.; Dionisio, M.; et al. Actions for prevention and control of health threats related to maritime transport in European Union. Travel Med. Infect. Dis. 2013, 11, 238-242. [CrossRef] [PubMed]

8. Hadjichristodoulou, C.; Mouchtouri, A.V.; Martinez, C.V.; Nichols, G.; Riemer, T.; Rabinina, J.; Swan, C.; Pirnat, N.; Sokolova, O.; Kostara, E.; et al. Surveillance and control of communicable diseases related to passenger ships in Europe. Int. Marit. Health 2011, 62, 138-147. [PubMed]

9. Instituto de Salud Carlos III and Spain. EU ShipSan Act Joint Action; EU SHIPSAN ACT joint action: Madrid, Spain, 2014.

10. Mouchtouri, V.A.; Nichols, G.; Rachiotis, G.; Kremastinou, J.; Arvanitoyannis, I.S.; Riemer, T.; Jaremin, B.; Hadjichristodoulou, C. State of the art: Public health and passenger ships. Int. Marit. Health 2010, 61, 49-98. [PubMed]

11. Stamatakis, C.E.; Rice, M.E.; Washburn, F.M.; Krohn, K.J.; Bannerman, M.; Regan, J.J. Maritime illness and death reporting and public health response, United States, 2010-2014. Travel Med. Infect. Dis. 2017, 19, 16-21. [CrossRef]

12. Rapid Risk Assessment. Outbreak of Hepatitis A Virus Infection in Travellers Returning from Egypt; European Centre for Disease Prevention and Control: Stockholm, Sweden, 2013.

13. European Centre for Disease Prevention and Control. Communicable Disease Threats Report, 14-20 July 2019, Week 29; European Centre for Disease Prevention and Control: Stockholm, Sweden, 2019.

14. US Centers for Disease Control and Prevention. Guidance for Cruise Ships on Varicella (Chickenpox) Management; US Centers for Disease Control and Prevention: Atlanta, GA, USA, 2014.

15. World Health Organization. Handbook for Management of Public Health Events on Board Ships; World Health Organization: Geneva, Switzerland, 2016.

16. EU SHIPSAN ACT joint action. European Manual for Hygiene Standards and Communicable Diseases Surveillance on Passenger Ships; EU SHIPSAN: Larissa, Greece, 2016.

17. European Council. Decision No 1082/2013/EU of the European Parliament and of the Council of 22 October 2013 on Serious Cross-Border Threats to Health an Repealing Decision No 2119/98/EC. Available online: https://ec.europa.eu/health/sites/health/files/preparedness_response/docs/decision_serious_ crossborder_threats_22102013_en.pdf (accessed on 26 July 2019).

18. World Health Organization. International Health Regulations, 3rd ed.; World Health Organization: Geneva, Switzerland, 2016.

19. EU SHIPSAN ACT Joint Action. The Impact on Maritime Transport of Health Threats Due to Biological, Chemical and Radiological Agents, Including Communicable Diseases. Available online: http://www. shipsan.eu (accessed on 26 July 2019).

20. Moher, D.; Moher, D.; Liberati, A.; Altman, D.G. Preferred reporting items for systematic reviews and meta-analyses: The PRISMA statement. PLoS Med. 2009, 6, e1000097. [CrossRef]

21. EU SHIPSAN ACT joint action. EU SHIPSAN ACT Information System (SIS). Available online: https: //sis.shipsan.eu (accessed on 29 July 2019). 
22. Nieto-Vera, J.; Masa-Calles, J.; Dávila, J.; Molina-Font, J.; Jiménez, M.; Gallardo-García, V.; Mayoral-Cortés, J.M. An Outbreak of Measles in Algeciras, Spain, 2008-A Preliminary Report. Available online: http://www. eurosurveillance.org/View Article.aspx?ArticleId=18872 (accessed on 15 May 2008).

23. Hannah, C. Lewis, Outbreaks of Measles. personal communication, 2015.

24. Diphtheria acquired during a cruise in the Baltic Sea. Commun. Dis. Rep. CDR Wkly. 1997, 7, 207.

25. Ellis, M.; Luna-Pinto, C.; George, T.; Regan, J.J.; Marin, M.; Lopez, A.; Rivera-Garcia, B.; Tardivel, K. Notes from the Field: Varicella fatality on a cargo vessel-Puerto Rico, 2015. Morb. Mortal. Wkly. Rep. 2017, 66, 410. [CrossRef]

26. Farr, W.; Gonzalez, M.J.; Garbauskas, H.; Zinderman, C.E.; Lamar, J.E. Suspected meningococcal meningitis on an aircraft carrier. Mil. Med. 2004, 169, 684-686. [CrossRef]

27. Munne, M.S.; Altabert, N.R.; Vladimirsky, S.N.; Arribere, M.G.; Ortali, S.F.; Sijvarger, C.; Otegui-Mares, L.O.; Soto, S.S.; Brajterman, L.S.; González, J.E. Molecular surveillance of hepatitis A virus in Argentina: First subgenotype IB detected in a traveler. Ann. Hepatol. 2014, 13, 404-406. [CrossRef]

28. Filia, A.; Bella, A.; del Manso, M.; Rota, M.C.; Magurano, F.; Nicoletti, L.; Declich, S. Extensive Nosocomial Transmission of Measles Originating in Cruise Ship Passenger, Sardinia, Italy, 2014. Emerg. Infect. Dis. 2015, 21, 1444-1446. [CrossRef] [PubMed]

29. Stefanelli, P.; Fazio, C.; Neri, A.; Isola, P.; Sani, S.; Marelli, P.; Martinelli, C.; Mastrantonio, P.; Pompa, M.G. Cluster of Invasive Neisseria Meningitidis Infections on a Cruise Ship, Italy, October 2012. Available online: http://www.eurosurveillance.org/ViewArticle.aspx?ArticleId=20336 (accessed on 13 December 2012).

30. Bernard, H.; Frank, C. Cluster of Hepatitis A Cases among Travellers Returning from Egypt, Germany, September through November 2008. Available online: https://edoc.rki.de/bitstream/handle/176904/457/ 20KmhhazbrGaU.pdf?sequence=1 (accessed on 22 January 2009).

31. Lanini, S.; Capobianchi, M.R.; Puro, V.; Filia, A.; Del Manso, M.; Kärki, T.; Nicoletti, L.; Magurano, F.; Derrough, T.; Severi, E.; et al. Measles Outbreak on a Cruise Ship in the Western Mediterranean, February 2014, Preliminary Report. Available online: http://www.eurosurveillance.org/ViewArticle.aspx?ArticleId=20735 (accessed on 13 March 2014).

32. Maloney, S.A.; Cetron, M. Investigation and management of infectious diseases on international conveyances (airplanes and cruise ships). In Textbook of Travel Medicine and Health, 2nd ed.; Dupont, H.L., Steffen, R., Eds.; BC Decker: Hamilton, ON, Canada, 2001.

33. Cozza, V.; Chironna, M.; Leo, C.; Prato, R. Letter to the Editor: Measles on the Cruise Ship: Links with Virus Spreading into an Emergency Department in Southern Italy. Available online: http://www.eurosurveillance. org/ViewArticle.aspx?ArticleId=20800 (accessed on 15 May 2014).

34. From the Centers for Disease Control and Prevention. Rubella among crew members of commercial cruise ships-Florida, 1997. JAMA 1998, 279, 348-350.

35. Kuhlman, J.C. Mumps outbreak aboard the USS Reuben James. Mil. Med. 1994, 159, 255-257. [CrossRef] [PubMed]

36. Couturier, E.; Roque-Afonso, A.M.; Letort, M.J.; Dussaix, E.; Vaillant, V.; De Valk, H. Cluster of Cases of Hepatitis A with a Travel History to Egypt, September-November 2008, France. Available online: http://www.eurosurveillance.org/ViewArticle.aspx?ArticleId=19094 (accessed on 22 January 2009).

37. Robesyn, E.; Micalessi, M.I.; Quoilin, S.; Naranjo, M.; Thomas, I. Cluster of Hepatitis A Cases among Travellers Returning from Egypt, Belgium, September through November 2008. Available online: http: //www.eurosurveillance.org/ViewArticle.aspx?ArticleId=19095 (accessed on 22 January 2009).

38. Acevedo, F.; Diskin, A.L.; Dahl, E. Varicella at sea: A two-year study on cruise ships. Int. Marit. Health 2011, 62, 254-261. [PubMed]

39. Schlaich, C.; Riemer, T.; Lamshöft, M.; Hagelstein, J.-G.; Oldenburg, M. Public health significance of chickenpox on ships-Conclusions drawn from a case series in the port of Hamburg. Int. Marit. Health 2010, 61, 28-31. [PubMed]

40. Cramer, E.H.; Slaten, D.D.; Guerreiro, A.; Robbins, D.; Ganzon, A. Management and control of varicella on cruise ships: A collaborative approach to promoting public health. J. Travel Med. 2012, 19, $226-232$. [CrossRef] [PubMed]

41. Rice, M.E.; Slaten, D.D.; Guerreiro, A.; Robbins, D.; Ganzon, A. Maritime varicella illness and death reporting, U.S., 2010-2015. Travel Med. Infect. Dis. 2018, 23, 27-33. [CrossRef] 
42. Idnani, N. Varicella among seafarers: A case study on testing and vaccination as a cost-effective method of prevention. Int. Marit. Health 2010, 61, 32-35. [PubMed]

43. Hansen, H.L.; Andersen, P.L.; Brandt, L.; Broløs, O. Antibodies against hepatitis viruses in merchant seamen. Scand. J. Infect. Dis. 1995, 27, 191-194. [CrossRef]

44. Hawkins, R.E.; Malone, J.D.; Cloninger, L.A.; Rozmajzl, P.J.; Lewis, D.; Butler, J.; Cross, E.; Gray, S.; Hyams, K.C. Risk of viral hepatitis among military personnel assigned to US Navy ships. J. Infect. Dis. 1992, 165, 716-719. [CrossRef] [PubMed]

45. Mazokopakis, E.; Vlachonikolis, J.; Philalithis, A.; Lionis, C. Seroprevalence of hepatitis A, B and C markers in Greek warship personnel. Eur. J. Epidemiol. 2000, 16, 1069-1072. [CrossRef] [PubMed]

46. Regan, J.J.V.; Scott, J.; Brown, C.M. Infectious illnesses on cruise and cargo ships, in Infectious Diseases. A geographical guide. Infect. Dis. 2017, 35-44. [CrossRef]

47. World Health Organization. International Medical Guide for Ships, 3rd ed.; Including the Ship's Medicine Chest; World Health Organization: Geneva, Switzerland, 2007.

48. World Health Organizartion. Handbook Inspection of Ships and Issuance of Ship Sanitation Certificates 2011; World Health Organizartion: Geneva, Switzerland, 2011.

49. International Labour Organization. Maritime Labour Convention; International Labour Organization: Geneva, Switzerland, 2006.

50. Morof, D.C. Pregnant Travelers. In CDC Yellow Book 2018 Health Information for International Travel; Centers for Disease Control and Prevention: Atlanta, GA, USA, 2018.

51. World Health Organization. Immunization, Vaccines and Biologicals. New Measles Surveillance Data for 2019; World Health Organization: Geneva, Switzerland, 2019.

52. European Centre for Disease Prevention and Control, RISK ASSESSMENT. Who Is at Risk For Measles in the EU/EEA? Identifying Susceptible Groups to Close Immunity Gaps towards Measles Elimination. Available online: https://ecdc.europa.eu/sites/portal/files/documents/RRA-Measles-EU-EEA-May-2019.pdf (accessed on 28 May 2019).

53. The European Parliament. European Parliament Legislative Resolution of 18 April 2019 on the Proposal for a Regulation of the European Parliament and of the Council Establishing a European Maritime Single Window Environment and Repealing Directive 2010/65/EU (COM(2018)0278-C8-0193/2018-2018/0139(COD)). (Ordinary Legislative Procedure: First Reading). 2019. Available online: http://www.europarl.europa.eu/ doceo/document/TA-8-2019-0434_EN.html\#title1 (accessed on 29 July 2019). 